\title{
Administrator Perspectives of Community College Career and Technical Programs A Principal Component Analysis
}

\author{
Thomas Gauthier ( $\nabla$ tgauthier28.tg@gmail.com ) \\ Palm Beach State College https://orcid.org/0000-0002-4987-0483
}

\section{Research Article}

Keywords: career and technical education, community college, leadership, higher education, vocational education, postsecondary

Posted Date: February 22nd, 2022

DOI: https://doi.org/10.21203/rs.3.rs-1365901/v1

License: @ (i) This work is licensed under a Creative Commons Attribution 4.0 International License. Read Full License 


\section{Abstract}

Community colleges facilitate most career and technical education (CTE) and workforce preparatory programs nationwide and are considered the premier institutions to administer these programs. This study explores community college administrator perspectives of CTE programs. The study recruited 17 participants representing 12 institutions in Florida's college system. Using the survey research method, a principal component analysis resulted in three factors extracted from the data and three significant correlations. Factors include social cognitive ability, learning outcomes, and curriculum and course content. The study concludes that administrators understand the intended meaning and value of CTE programs but do not appropriately appreciate the rigor or context for which these programs support the stakeholders.

\section{Introduction}

Community colleges are on the front line to prepare people for an evolving workforce. These institutions offer a variety of programs, including those that confer an associate degree, certificate, industry-recognized credential, remedial course work, corporate and continuing education, and a variety of short-term programs focused on economic development. While community colleges do many things well (Osterman, 2011), they are subjected to perpetual criticism. Community colleges for long have been criticized for their open-admissions policy, thus, being charged with educating students under a vale of ignorance. This criticism admonishes them for stunting educational growth and deferring people from gaining additional education.

While community colleges are criticized, the career and technical education (CTE) and economic development programs, sometimes referred to simply as workforce or workforce development (WD) initiatives, have also been labeled as programs for the less academically inclined and are too narrow in scope and breadth. Criticism has implied that CTE programs demoralize higher education (Lazerson, 2010) by perpetuating diversion by training students just enough so that they can compete for employment positions (Anthony P. Carnevale et al., 2018; Jenkins \& Fink, 2016; Larson et al., 2014; Monaghan \& Attewell, 2015). Community colleges roughly define CTE, and policymakers arbitrarily refer to workforce as CTE or a college's 'workforce' education. These institutions are organizations complete with an ecological system that sometimes compresses the members, often resulting in pathway dependency.

There is no question that community colleges face barriers to supporting the community. Finding faculty is a profound obstacle in this effort, often resulting in instructors with the minimum credentials allowed to teach courses. Career and technical education often employ faculty with extensive industry experience and focuses less on academic credentials. This paradigm, while well-intentioned, appears problematic as CTE faculty struggle to broaden the curriculum to include general education competencies. For this reason, CTE has been labeled too narrow in scope; thus, students learn the technical skills required to earn employment but experience challenges in the workforce post phase one employment (Bettinger \& Soliz, 2016; Bray et al., 2011; Frentzos, 2005; Hinchliffe \& Jolly, 2011; Neneh, 2019). While there is positive economic data aligned with CTE, employers are increasingly concerned with the lack of social cognitive ability of recent CTE graduates.

Community college administrators drive the culture on campus and can work to strengthen CTE and WD programs in conjunction with the faculty (Gauthier, 2021b). The purpose of this study is to explore administrator perspectives of community college CTE programs. The following central research question was developed to help guide and frame the study, what are administrator perceptions of community college CTE programs? To further define the scope of this study, the following sub-questions were developed,

1. What are the common factors in the data?

2. What factors are more prevalent for the participants than others?

\section{Organization}

This paper is organized in the following manner. The related literature is presented, and then the study's context is discussed. Next, the researcher presents the theoretical framework used to frame and define the scope of the study, followed by the context 
and limitations. The study's context and limitations are followed by the research method, including a description of the survey study method. The research site and sample population are discussed and the data collection tool.

Then, the researcher presents the study's findings, including the participants' demographics and the reliability and results of the study. Next, the significant factors derived through Principal Component Analysis are presented and defined. Following the findings, the researcher discusses the findings and their implications on practice. Discussion and implications are followed by the conclusion and recommendations for additional research.

\section{Review Of Related Literature}

A community college is an agent of society charged with supporting the local economy and preparing students for additional education. These two-year institutions were championed to support the associate degree and prepare students to transfer to fouryear colleges or universities. Over time community colleges were labeled as second chance colleges (Handel, 2007) because students who were not accepted into a university resorted to enrolling in a community college program. During an economic recession, community colleges were a mechanism used to support labor by offering remedial course work and professional development to people who lost their jobs or were looking to reskill or upskill.

Tension over the purpose of a community college has grown recently. As tuition increases, society questions the value of earning a higher education, and the sentiment that college is not for everyone has reached the associate degree level. As a result, community colleges are being pressured to offer an unusual amount of short-term and noncredit-bearing programs. The thought is that the community colleges should develop and focus on short-term and noncredit bearing programs to reduce unemployment and provide local industry with the labor it needs for production. Developing programs that train students just enough so that they can get a job is a community college policy that has been heavily criticized in the past (Bailey et al., 2015; Goldrick-Rab, 2010; Hoelscher et al., 2008; Rosenbaum et al., 2007). Employers indicated that recent community college graduates lack the social and emotional skills required to function on a day-to-day basis resulting, in some cases, in termination (Tuor Sartore \& Backes-Gellner, 2020).

\section{Theoretical Framework}

Path dependency has been used in various disciplines, including law, politics, medicine, education, and social science. The theory is premised on an institution's decision-making process and how these decisions interact with the broader social, economic, and political environment (Ghosh, 2019; Kay, 2005). Organizations seek safety concerning decision-making by relying on the historical context of the decision. Unfortunately, many intuitions view policy-making as one-directional within the comfort of historical dependency (Krücken, 2003). Thus, institutions entrenched in dependency cannot agree on the appropriate policy to advance the organization.

Path dependence considers the value of practice in the past and assumes that those practices will be valuable in the future (Peters et al., 2005). Currently, community colleges are under unusual political pressure to bolster enrollment to support economic development. The college uses resources to prepare and facilitate short-term credit and noncredit bearing CTE programs to supply labor to the industry and reduce the unemployment figures. Community colleges have supported economic advancement for years. However, the pressure to offer substandard higher education programs that train students just enough to earn employment quickly is a new phenomenon. It has created concern about the quality and worth of the education they provide. A path that serves its purpose when facilitated correctly. This pathway, therefore, cannot be assumed to support the current needs of society in that leveraging the quality of education will not sustain economic improvement or growth.

The addled nature of community colleges is articulated when under pressure; the institutions seem to equivocate on their mission and values, thus entering into a path-dependent risk (Schreyögg et al., 2011). Community colleges spend time and other resources, including industry partnerships, developing programs, and facilitating them. The risk, therefore, is that the college plans to support the economy in the present and does not include succession or long-term contingencies into the plan. While satisfying the economy, this risk inhibits the institution from providing quality education and neglects lifelong learning. Inherently, path-dependent risk supplants the functions of an educational institution for that of a business and resorts to acting as a job 
placement entity. Indeed, there is no question that the further entrenched an organization is, the more challenging it becomes to eradicate dependency.

\section{Context And Limitations}

Community college administrators are often assigned areas of oversight for which they have no expertise. The design of this study does not attempt to understand the level to which the participants have expertise in the CTE area they oversee. Thus, the study does not attempt to bracket participant bias. Career and technical education and workforce preparatory programs carry different definitions depending on the institution offering the programs. Therefore, this study relied on the individual research site's definition of the terms, leading to an unequal alignment of responses.

Another limitation is the research sites themselves. Florida converted their community college into state colleges to align with the conference of bachelorette degrees. Therefore, the participants could have an ambivalent feeling about the purpose and nature of the institution. These feelings could draw questions in terms of the appropriateness of state colleges offering CTE and workforce credit-bearing and noncredit bearing programs, leading to animosity and survey responses influenced by this animosity.

\section{Method}

This study examined administrator perspectives of community college CTE programs using the survey research method (Fowler, 2014). A survey allows the researcher to evaluate the participant perceptions of the topic being investigated in terms of relationships and correlations (Sapsford, 2007). Survey studies include the process of collecting responses to research questions or statements then translating them to data points (Neuman, 1991).

Research Site. Community colleges in Florida were approved to offer bachelor's degrees and thus were rebranded as state colleges (Wattenbarger \& Albertson, 2007). However, Florida's state colleges continue to act as community colleges in that they offer open enrollment, associate degrees, certificates, industry-recognized certifications, economic development, and continuing education programs.

The research site had to be a 'community college' and offer at least one program that the college considered CTE or workforce development to qualify for this study. In addition to the intuition classifying programs as CTE, those programs had been Perkins eligible (Perkins Collaboative Resource Network, 2021). Secondary school CTE programs were excluded from this study. Private two-year institutions, four-year institutions, career center seminars, and job placement training programs were excluded.

Participants. The researcher sent a request to participate to administrators from state colleges in Florida. Administrators who agreed to participate were sent a consent form and a link to a digital survey. Participants agreed to consent by completing the survey as specified in the consent form. Administrators were recruited via the research site's digital directory and were defined as a person in the role of any-rank dean, executive director, director, or vice president of academic affairs or student services. All other vice president roles and the role of college president were excluded from this study. Department chairs, staff, and faculty members were excluded.

Data Collection Instrument. A survey containing 43 statements of opinion was used to collect data from the participants. Statements were identified from the literature and aligned with CTE concepts such as employment, soft skills, stigmatization, faculty credentials, and the purpose of CTE. The survey asked participants to score each statement based on their level of agreement on a scale of 0-8 ( 0 - do not agree, 8 - agree) with the values in between offering the participant the opportunity to rank their level of agreement with the statement (Sapsford, 2007). In addition, the survey tool asked the participants six demographic questions. Participants were given two weeks to complete the digital survey and were issued a reminder at the start of the second week.

Data Analysis. Data were analyzed with JASP (Just Another Statistical Program), XLSTAT to run a correlational matrix, and Principal Component Analysis (PCA). Survey reliability using Cronbach's alpha was tested using Excel's two-factor ANOVA 
without replication analysis tool. Finally, descriptive statistics were analyzed to identify themes or patterns in the data (Harman, 1967; Osborne, 2014 ).

\section{Findings}

One hundred - seventeen participants were contacted, representing 21 of Florida's 28 state colleges. After two weeks, 17 participants representing 12 state colleges completed a survey. Therefore, this study had a participant response rate of $14 \%$ and a distribution response rate of $57 \%$. The majority held doctorate degrees $(52.9 \%)$ and overwhelmingly represented deans at $56.3 \%$. Respondents reported being between 56 and 65 years of age and practicing between 16-20 years. Most participants reported as female (58\%), and $82.4 \%$ indicated that they were employed by a state college (refer to table 1 for complete demographics).

Cronbach's alpha was used to test for reliability, which resulted in a score of .70, which is in the acceptable range (Kline, 1994; Osborne, 2014 ). Concerning the participants' responses to the statements of opinion, they disagreed with less than 1 percent of the statements (Table 2); 41 percent reported as neutral (Table 3), and 48 percent agreed with the statements (Table 4).

\section{Table 1}

Participant Demographical Information $(n=17)$

\begin{tabular}{ll} 
Question & Response $(\mathrm{pct})$ \\
\hline Highest degree earned & 52.9 Doctorate \\
& 47.1 Masters \\
\hline What is your role? & 56.3 Dean \\
& 18.8 Assistant or Associate Dean \\
\hline What is your age? & 47.1 between $56-65$ years of age \\
& 23.5 between $66-75$ years of age \\
& 17.6 between $46-55$ years of age \\
& 11.8 between $36-45$ years of age \\
\hline Experience in higher education & 23.5 between $16-20$ years \\
& 17.6 between $11-15 ; 21-25$ years \\
& 11.8 6-10 years; $11-15$ years \\
\hline What is your gender? & 58.8 Female \\
& 41.2 Male \\
\hline What type of institution are you employed in? & 82.4 State college \\
& 17.6 community college
\end{tabular}

\section{Statements of Opinion}

\section{Table 2}

Statements of Disagreement $(n=17)$ 


\begin{tabular}{lll} 
Statement & Mean Score & SD \\
\hline 4. CTE programs demoralize higher education & 1.00 & 1.658 \\
\hline 17. CTE students do not have the stamina to study an academic subject & 1.58 & 2.123 \\
\hline 21. An apprenticeship is not an appropriate CTE program & 1.64 & 2.206
\end{tabular}

\section{Table 3}

Statements of Neutral $(n=17)$

\begin{tabular}{|c|c|c|}
\hline Statement & $\begin{array}{l}\text { Mean } \\
\text { Score }\end{array}$ & SD \\
\hline 3. CTE programs are stigmatized in society & 5.647 & 2.029 \\
\hline 9. CTE program should be for-credit & 5.176 & 2.675 \\
\hline 10. CTE programs should be noncredit & 3.647 & 2.783 \\
\hline $\begin{array}{l}\text { 12. CTE programs should have articulation partnerships to help students transfer to a four-year } \\
\text { program easily }\end{array}$ & 5.824 & 2.007 \\
\hline 13. CTE programs should include a general education component & 5.000 & 2.828 \\
\hline 14. The habits of mind are evident in CTE programs & 5.647 & 1.579 \\
\hline 15. CTE competencies should include a mix of old trade instruction and new high-tech instruction & 5.882 & 2.118 \\
\hline 20. all CTE programs should have an internship component & 5.882 & 2.176 \\
\hline 22. CTE programs should incorporate academic as well as technical education & 5.647 & 2.737 \\
\hline 25. People enroll in CTE programs for various reasons other than to get a job & 3.294 & 2.867 \\
\hline 26. CTE programs should use a micro-credentialing structure & 5.235 & 1.954 \\
\hline 28. It is appropriate for CTE programs to offer students just enough to get a job & 3.765 & 2.538 \\
\hline 29. Career is referred to as employment & 4.529 & 2.348 \\
\hline 30. CTE programs must have a learn at work component & 5.176 & 2.243 \\
\hline 35. CTE education should lead to additional education & 4.765 & 1.954 \\
\hline 41. CTE faculty should have at least an associate degree & 5.471 & 2.503 \\
\hline 42. CTE credits should transfer to a four-year college or university & 4.824 & 2.128 \\
\hline 43. High school students should take dual enrollment in community college noncredit CTE pro & 5.000 & 2.574 \\
\hline
\end{tabular}

\section{Table 4}

Statements of Agreement ( $n=17)$ 
1. Career and technical education leads to employment upon graduation

2. Community colleges are the best institutions to offer CTE

5. CTE programs are an alternative to academic programs

6.23 2.611

6. CTE programs include a rigorous curriculum 7.00 1.323

7. CTE learning outcomes are aligned with workplace requirements 6.64 1.801

8. Industry advisory committees are an essential factor in contemporary CTE

7.41

1.176

11. CTE faculty are experts in their field

6.70

1.532

16. Math and science play a significant role in CTE education

6.11

1.409

18. Career pathways must be included in all CTE program offerings

6.00

2.121

19. CTE students must be exposed to soft skills

7.17

1.425

23. CTE programs should prepare graduates for sustainable employability and growth

7.76

0.562

24. People enroll in CTE programs to get a job

7.00

1.581

27. Employers need to play a role in developing a CTE curriculum

6.76

1.200

31. CTE programs should engage and motivate students to learn

7.35

1.320

32. CTE programs should advance a student's social and emotional development

6.58

1.502

33. The purpose of CTE programs is to offer students appropriate learning opportunities

6.29

1.404

34. The purpose of CTE programs is to earn employment

6.41

1.805

36. CTE programs should foster a culture of lifelong learning

7.00

1.369

37. CTE students should learn transferable skills that will serve them well in the innovation economy?

7.11

39. CTE programs help close the equity gap in society

6.41

1.970

40. CTE programs prepare graduates for long-term careers

6.58

1.906

\section{Principal Components}

A preliminary Principal Component Analysis (PCA) resulted in 5 components with eigenvalues greater than 1. However, the proportion variance of two components was insignificant, and multiple redundant statements were loaded on a fourth component. Therefore, the PCA test was conducted again with a Promax rotation (see figure 1), resulting in three significant factors.

\section{Table 5}

Component Characteristics After Rotation

\begin{tabular}{llll} 
& F1 & F2 & F3 \\
\hline Eigenvalue & 9.18 & 6.11 & 5.72 \\
\hline Variability (\%) & 21.90 & 14.60 & 13.60 \\
\hline Cumulative \% & 21.90 & 36.40 & 50.00
\end{tabular}


Factor 1 loaded on statements of opinion that align with the value and rigor of CTE. Highest values that loaded include statements 10,33,11,39 (see table 6). Factor 2 loaded on statements that align with the program's ability to support sustainable employability and growth; highest values loaded on statements 29,40,8,4,23 (see table 7). Factor 3 loaded on statements aligned with the CTE program's purpose; highest values loaded on statements 21,38,24,31 (see table 8).

\section{Table 6}

Statements that loaded on factor 1

\begin{tabular}{llc} 
& Statement of Opinion & Value \\
\hline VAR010 & CTE programs should be noncredit & 0.85 \\
\hline VAR033 & The purpose of CTE is to offer students an appropriate learning opportunity & 0.85 \\
\hline VAR011 & CTE faculty are experts in their field & -0.8 \\
\hline VAR039 & CTE programs help close the equity gap in society & -0.8
\end{tabular}

Table 7

Statements that loaded on factor 2

\begin{tabular}{llc} 
& Statement of Opinion & Value \\
\hline VAR029 & Career is referred to as employment & 0.84 \\
\hline VAR040 & CTE programs prepare graduates for long-term careers & 0.83 \\
\hline VAR008 & Industry advisory committees are an essential factor in CTE & 0.77 \\
\hline VAR004 & CTE programs demoralize higher education & 0.76 \\
\hline VAR023 & CTE programs should prepare graduates for sustainable employment and growth & 0.73
\end{tabular}

\section{Table 8}

Statements that loaded on factor 3

\begin{tabular}{clc} 
& Statement of Opinion & Value \\
\hline VAR021 & An apprenticeship is not an appropriate CTE program & 0.91 \\
\hline VAR038 & CTE programs should confer industry certifications only & 0.86 \\
\hline VAR024 & People enroll in CTE programs to get a job & 0.84 \\
\hline VAR031 & CTE programs should engage and motivate students to learn & -0.8
\end{tabular}

\section{Discussion And Implications}


Factor analysis was used to reduce the data to smaller and more manageable metrics. The factors revealed that administrators feel that community college CTE programs should be holistic in that they support a student's goal to be successful upon completion. The rating scale $0-8$ offered the participants an opportunity to score and rate their level of agreement with the statement. The central research question was administrator perceptions of community college CTE programs? To further define the scope of this study, the following sub-questions were developed,

1. What are the common factors in the data?

2. What factors are more prevalent for the participants?

In their effort to satisfy the stakeholders, community college CTE programs create tension with the ambiguity of vocationalism (Lazerson, 2010). Community colleges often rely on economic reporting to help dictate the type and discipline of programs to offer, implicitly neglecting those industries that do not fall into a high wage, high demand category. As a result, community colleges resort to offering short-term CTE programs, often noncredit bearing, a concern according to the data (refer to statement 9). Short-term CTE programs do not include the habits of mind or transferable skills (refer to statement 37). Interestingly, the participants agreed with statement 7, but they responded to the statement regarding the program's utility and did not follow the social cognitive learning outcomes.

The participants disagreed with statement 21. Apprenticeships have been criticized for their lack of a holistic nature and being too narrow in scope and breadth (OECD., 2018). An apprenticeship could be a gateway for some into a long-standing career or lead to a "springboard job[s]" (Lamback \& Cahill, 2020, p. 73); the data draws the hypothetical question, are community colleges the best institutions to facilitate apprenticeships? The participants agreed with statement 37 that students should learn transferable skills as part of their CTE program, but an apprenticeship does not offer interdisciplinary study. Political pressure often influences community college leadership to offer short-term programs and apprenticeships to support economic growth. Community colleges are higher education institutions, and they must recognize their responsibility to expose students to civic learning across the curriculum and divisions of the college (Deming, 2017; Hirsch, 2019; Lewis \& Lagemann, 2012). Thus, institutions that choose to neglect their civic obligations and offer students just enough education so they can get a job are often addled about their mission and an inherent misconception of higher education as a private gain and not as a public good (Hansen, 2015).

The participants felt that transferable skills are an essential concept in contemporary CTE, and these skills should be included in the learning outcomes and course content throughout the CTE disciplines. Transferable skills are a hallmark of the career pathways movement, and apprenticeships are not exempt from the portable credential requirement (Hamilton, 2020). However, stackable credentials and transferable skills are excluded in the "cul-de-sac" (p. 121) nature of short-term, noncredit-bearing CTE programs community colleges have become accustomed to offering.

Participants agreed that CTE should provide sustainable employability growth and be a mechanism for life-long learning (23). However, the participants equivocated on the statements aligned with the elements to support statement 23. For example, the participants were neutral on statement number 42 (CTE credits should transfer to a four-year college or university) and statement number 22 (CTE programs should incorporate academic and technical education). Contradiction such as this draws questions about the level to which community college administrators understand CTE and the integrity of the institutional leaders. Do they support CTE because of the meaning and value of these programs, or do they support CTE because of the business venture community colleges feel they are obligated to portray?

\section{Conclusion}

A survey study asked community college administrators to rate their level of agreement with 43 statements of opinion using a scale from 0 (do not agree) to 8 (most agree), with the numbers in between allowing variations of opinion. A PCA revealed three factors, social cognitive ability, program learning outcomes, curriculum, and course content. The study concludes that the participants believe that CTE programs should be a mechanism to support student growth and development; these programs must also support sustainable employability in that completers can use their education to move from static employment to a 
career (Collins, 2020; Lamback et al., ND). Embedded in sustainable employability are technical and social competencies that employers value the most in employees (Deming, 2017). Social competencies include communication, teamwork skills, reasoning, and motivation, to name a few, including the ability to engage in lifelong learning.

Administrators could improve upon their CTE offerings by strengthening instructor credentialing requirements to broaden curriculum interaction (Fletcher Jr et al., 2018) and offer meaningful professional development focused on soft skills and their integration with core courses (Hamilton, 2020). The(Lambert, 2020, p. 43)re is no question that the past is a prolog for community colleges entrenched in pathway dependency (Anthony P Carnevale et al., 2018; Gauthier, 2021a; Margolis, 2009). These addled institutions do not support the stakeholders. Career and technical programs facilitated well include project-based learning opportunities where students have agency in the learning process. They include the habits of mind (Grossman et al., 2021) required by contemporary employers to keep pace with an evolving economy and technology. Indeed, community colleges must do their part in developing curricula of a holistic nature to include academic and technical competencies to enable interdisciplinary and transferable knowledge (Hirsch, 2019).

\section{Declarations}

\section{Competing interests:}

The author declares no competing interests.

\section{References}

Bailey, T., Jaggars, S. S., \& Jenkins, D. (2015). Redesigning america's community colleges. Harvard University Press.

Bettinger, E., \& Soliz, A. (2016). Returns to vocational credentials: Evidence from ohio's community and technical colleges. A capsee working paper. Center for Analysis of Postsecondary Education and Employment.

Bray, J., Painter, R., \& Rosin, M. (2011). Developing human capital: Meeting the growing global need for a skilled and educated workforce: Business and education working together can reduce barriers to employment and create new pathways to career development and job growth (Policy Paper: Creating New Pathways to

Career Development and Job Growth, Issue. McGraw-Hill Research Foundation. https://cte.careertech.org/sites/default/files/DevelopingHumanCapital.pdf

Carnevale, A. P., Strohl, J., Ridley, N., \& Gulish, A. (2018). Three educational pathways to good jobs: High school, middle skills, and bachelor's degree.

Carnevale, A. P., Strohl, J., Ridley, N., \& Gulish, A. (2018). Three educational pathways to good jobs: High school, middle skills, and bachelor's degree. The Georgetown University Center on Education and the Workforce https://vtechworks.lib.vt.edu/bitstream/handle/10919/86987/EducationalPathways.pdf?sequence=1\&isAllowed=y

Collins, M. L. (2020). Putting work at the center of community college completion reform: The college mobility narrative in the united states. In N. Hoffman \& M. L. Collins (Eds.), Teaching students about the world of work (pp. 21-33). Harvard Education Press.

Deming, D. J. (2017). The growing importance of social skills in the labor market*. The Quarterly Journal of Economics, 132(4), 1593-1640. https://doi.org/10.1093/qje/qjx022

Fletcher Jr, E. C., Warren, N. Q., \& Hernández-Gantes, V. M. (2018). Preparing high school students for a changing world: College, career, and future ready learners. Career and Technical Education Research, 43(1), 77-97. https://doi.org/10.5328/cter43.1.77

Fowler, J. F., Jr. (2014). Survey research methods (5 ed.). Sage

Page 10/13 
Frentzos, D. (2005). Credit and non-credit community college enrollment and the economy. (undetermined). Community College Enterprise, 11(1), 93-103. http://search.ebscohost.com/login.aspx?

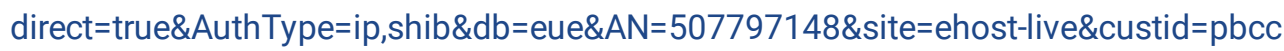

Gauthier, T. (2021a). Community college pathways' conflict. The Journal of Competency-Based Education, 6(2). https://doi.org/10.1002/cbe2.1232

Gauthier, T. (2021b). A survey of faculty perceptions of community college career and technical education. Journal of Research in Technical Careers, 5(2), 45-62. https://doi.org/10.9741/2578-2118.1106

Ghosh, B. N. (2019). Dependency theory revisited. Routledge.

Goldrick-Rab, S. (2010). Challenges and opportunities for improving community college student success. Review of Educational Research, 80(3), 437-469.

Grossman, P., Herrmann, Z., Kavanagh, S. S., \& Dean, C. G. P. (Eds.). (2021). Core practices for project-based learning: A guide for teachers and leaders Harvard Education Press

Hamilton, S. F. (2020). Career pathways for all youth: Lessons from the school-to-work movement. Harvard Education Press. Handel, S. J. (2007). Second chance, not second class: A blueprint for community-college transfer. Change: The Magazine of Higher Learning, 39(5), 38-45.

Hansen, E. T. (2015). Liberated consumers and the liberal arts college. In E. C. Lagemann \& H. Lewis (Eds.), What is college for?: The public purpose of higher education (pp. 63 - 85). Teachers College Press.

Harman, H. H. (1967). Modern factor analysis (Second ed.). The University of Chicago Press (1960)

Hinchliffe, G. W., \& Jolly, A. (2011). Graduate identity and employability. British Educational Research Journal, 37(4), $563-584$. https://doi.org/10.1080/01411926.2010.482200

Hirsch, E. D. (2019). Why knowledge matters: Rescuing our children from failed educational theories. Harvard Education Press.

Hoelscher, M., Hayward, G., Ertl, H., \& Dunbar-Goddet, H. (2008). The transition from vocational education and training to higher education: A successful pathway? Research Papers in Education, 23(2), 139-151.

Jenkins, D., \& Fink, J. (2016). Tracking transfer new measures of institutional and state effectiveness in helping community college students attain bachelor's degrees. Community College Research Center, Teacher College, Columbia University https://academiccommons.columbia.edu/doi/10.7916/D8C24W80

Kay, A. (2005). A critique of the use of path dependency in policy studies. Public administration, 83(3), 553-571.

Kline, P. (1994). An easy guide to factor analysis Routledge

Krücken, G. (2003). Learning thenew, new thing': On the role of path dependency in university structures. Higher Education, 46(3), 315-339.

Lamback, S., \& Cahill, C. (2020). When can a job launch a career? What students need to know about the real economic opportunities of middle-skill work. In N. Hoffman \& M. L. Collins (Eds.), Teaching students about the world of work: A challenge to postsecondary educators (pp. 71-82). Harvard Education Press.

Lamback, S., Gerwin, C., \& Restuccia, D. (ND). When can it launch a career. Burningglass. https://www.burning-glass.com/wpcontent/uploads/BurningGlass_JFF_RealCareerLaddersReport.pdf 
Lambert, L. D. (2020). Rising with the machines embracing opportunity - and living your values - in an age of transformation. In W. J. Rothwell, P. E. Gerity, \& V. L. Carraway (Eds.), Workforce development guidlines for communtiy college professionals (Vol. 2, pp. 41-48). Rowman and Littlefield

Larson, L. M., Pesch, K. M., Surapaneni, S., Bonitz, V. S., Wu, T.-F., \& Werbel, J. D. (2014). Predicting graduation. Journal of Career Assessment, 23(3), 399-409. https://doi.org/10.1177/1069072714547322

Lazerson, M. (2010). Higher education and the American dream: Success and its discontents. Central European University Press.

Lewis, H., \& Lagemann, E. C. (2012). Renewing the civic mission of American higher education. In H. Lewis \& E. C. Lagemann (Eds.), What is college for? The public purpose of higher education (pp. 9-45). Teachers College Press.

Margolis, S. E. (2009). Path dependence and public policy: Lessons from economics. In L. Magnusson \& J. Ottosson (Eds.), The evolution of path dependence. Edward Elgar Publishing.

Monaghan, D. B., \& Attewell, P. (2015). The community college route to the bachelor's degree. Educational Evaluation and Policy Analysis, 37(1), 70-91.

Neneh, B. N. (2019). An empirical study of personality traits, job market appraisal and self-perceived employability in an uncertain environment. Higher Education, Skills and Work-Based Learning, 10(1), 255-274. https://doi.org/10.1108/heswbl-12-2018-0145

Neuman, W. L. (1991). Social research methods Allyn and Bacon

OECD. (2018). Oecd reviews of vocational education and training seven questions about apprenticeships answers from international experience. OECD.

Osborne, J. W. (2014 ). Best practices in exploritory factor analysis CreateSpace.

Osterman, P. (2011). The promise, performance and policies of community colleges. In B. Wildavsky, A. P. Kelly, \& K. Carey (Eds.), Reinventing higher education: The promise of innovation (pp. 129-158). Harvard Education Press.

Perkins Collaboative Resource Network. (2021). Perkins iv. U.S. Department of Education Office of Career, Technical, and Adult Education Division of Acadmeic and Technical Education. Retrieved March 16 from https://cte.ed.gov/legislation/about-perkinsiv

Peters, B. G., Pierre, J., \& King, D. S. (2005). The politics of path dependency: Political conflict in historical institutionalism. The journal of politics, 67(4), 1275-1300.

Rosenbaum, J. E., Deil-Amen, R., \& Person, A. E. (2007). After admission: From college access to college success. Russell Sage Foundation.

Sapsford, R. (2007). Survey research (Second ed.). Sage

Schreyögg, G., Sydow, J., \& Holtmann, P. (2011). How history matters in organisations: The case of path dependence. Management \& Organizational History, 6(1), 81-100.

Tuor Sartore, S. N., \& Backes-Gellner, U. (2020). Educational diversity and individual pay: The advantages of combining academic and vet graduates in the workplace. Empirical Research in Vocational Education and Training, 12(1), 1-21.

Wattenbarger, J. L., \& Albertson, H. T. (2007). A succinct history of the florida community college system. Association of Florida Colleges.

https://www.myafchome.org/assets/site/the\%20florida\%20community\%20college $\% 20$ system\%20history\%20with\%20update.pdf

\section{Figures}

Page $12 / 13$ 


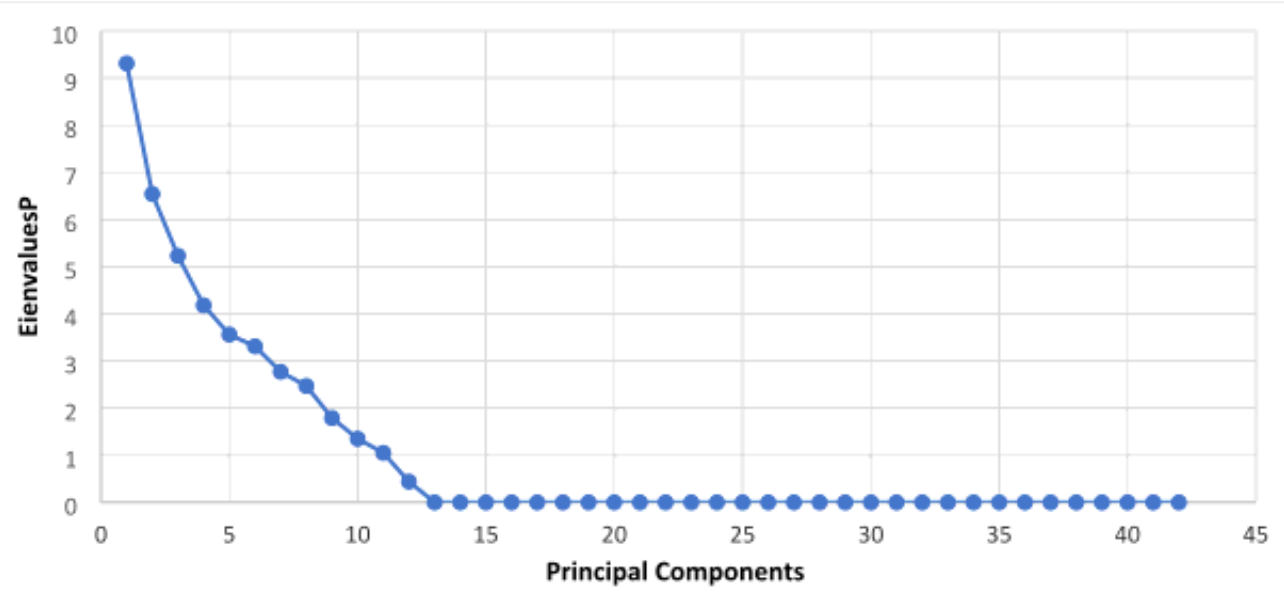

Figure 1

Scree Plot of Eigenvalues After Rotation 